\title{
Penetapan Kerugian Keuangan Negara merupakan Kewenangan BPK atau BPKP
}

\author{
Determination of State Financial Losses is the Authority \\ of the BPK or BPKP
}

\author{
Nurwahyu Safitri \\ Badan Keuangan Daerah (PHTT BKD) Kab. Bombana \\ E-mail: nurwahyurudi@gmail.com \\ Muh. Sabaruddin Sinapoy \\ Pascasarjana Universitas Halu Oleo \\ E-mail: sabaruddinsinapoy@yahoo.com \\ Kamaruddin Jafar \\ Pascasarjana Universitas Halu Oleo \\ E-mail: kamaruddinjafar.88@gmail.com
}

\begin{abstract}
This research aims to know the authority of BPK and BPKP in the process of determining state financial losses based on temporary audit reporting results from institutions authorized in provinces and districts/cities. With the many developing issues that reporting audit results causes state financial losses by officials who hold roles both in institutions and institutionally state.

The power of management of state finance and distribution of authority, has been regulated in Law Number 17 of 2003 concerning State Finance, Article 6 Paragraph (1) and (2), as follows: the president as head of government holds the power of management of state finance as part of government power BPK and BPKP have a task that is not much different but equally responsible in calculating state financial losses.

This research focuses on the competence of determining state financial losses is the authority of the BPK or BPKP which has been a problem in the process of determining state financial losses because based on Law Number 15 of 2006 corcerning the Supreme Audit Agency (BPK).

This research uses the normative approach method, based on the theories of experts and the concept of state financial losses being the basis for establishing state financial losses by BPK or BPKP. In the government environment the principle of centralization is used as the principle of autonomy for government power. Thus it can be concluded that the institution that determines the state financial losses is the BPK because in the Constitution of the Republic of Indonesia Article 23E, 23F, and $23 G$ it is clear that the BPK has a duty and authority over state financial losses based
\end{abstract}


on the law and as a function control in financing expenditures by authorized officials namely treasurer or holder of power in the institution.

Keyword: financial losses; authority; BPK; BPKP

Abstrak: Penelitian ini bertujuan untuk mengetahui kewenangan BPK dan BPKP dalam proses penetapan kerugian keuangan negara yang berdasarkan hasil pelaporan audit sementara dari lembaga yang berwenang di provinsi dan kabupaten/kota. Dengan banyaknya isu berkembang bahwa pelaporan hasil audit menimbulkan kerugian keuangan negara oleh pejabatyang memegang peranan baik dalam instansi maupun secara kelembagaan negara.

Kekuasaan pengelolaan keuangan negara dan pendistribusian kewenangan, telah diatur dalam Undang-Undang Republik Indonesia Nomor 17 Tahun 2003 tentang Keuangan Negara, Pasal 6 ayat (1) dan (2), sebagai berikut: presiden selaku kepala pemerintahan memegang kekuasaan pengelolaan keuangan negara sebagai bagian dari kekuasaan pemerintahan BPK dan BPKP memiliki tugas yang tidakjauh berbeda tapi sama-sama bertanggung jawab dalam penghitungan kerugian keuangan negara.

Penelitian ini fokus pada kompetensi penetapan kerugian keuangan negara merupakan kewenangan BPK atau BPKP yang mana selama ini menjadi masalah dalam proses penetapan kerugian keuangan negara karena berdasarkan UndangUndang Republik Indonesia Nomor 15 Tahun 2006 tentang Badan Pemeriksa Keuangan (BPK).

Penelitian ini menggunakan metode pendekatan normatif, berdasarkan teori para ahli dan konsep kerugian keuangan negara menjadi dasar untuk menetapkan kerugian keuangan negara oleh BPK atau BPKP. Dalam lingkungan pemerintahan asas desentralisasi di gunakan sebagai asas otonomi kekuasaan pemerintah.

Dengan demikian dapat disimpulkan bahwa lembaga yang menetapkan kerugian keuangan negara adalah BPK karena dalam Pasal 23E, 23F, dan 23G UndangUndang Dasar Negara Republik Indonesia Tahun 1945 telah jelas di terangkan BPK memiliki tugas dan kewenangan atas kerugian keuangan negara berdasarkan perintah undang-undang dan sebagai fungsi kontrol dalam pengeluaran pembiayaan oleh pejabat yang berwenang yakni bendahara atau pemegang kekuasaan pada lembaga tersebut.

Kata kunci: kerugian keuangan; kewenangan; BPK; BPKP

\section{PENDAHULUAN}

Kerugian Keuangan negara terjadi akibat kelalaian penggunaan anggaran berlebihan yang tidak sesuai tupoksi dan sasarannya. Kerugian Keuangan negara dalam dimensi hukum administrasi negara memiliki definisi yang jelas sebagai mana terdapat dalam Pasal 1 angka 22 Undang-Undang Republik Indonesia Nomor 1 Tahun 2004 tentang Perbendaharaan Negara dan Pasal 1 angka 15 Undang-Undang Republik Indonesia Nomor 15 tahun 2006 tentang Badan Pemeriksaan Keuangan (BPK) yang keduanya sama-sama mendefinisikan “Kerugian Keuangan Negara/daerah adalah kekurangan uang, surat berharga, dan barang yang nyata dan jumlahnya sebagai akibat perbuatan melawan hukum baik sengaja maupun lalai". Artinya keuangan negara dapat membentuk kerugian uang, surat berharga, dan barang dalam ruang lingkup definisi Keuangan Negara sebagaimana 
di atur dalam Undang-Undang Republik Indonesia Nomor 17 tahun 2003 tentang keuangan negara, Undang-Undang Republik Indonesia Nomor 15 tahun 2006 tentang Badan Pemeriksa Keuangan, dan Undang-Undang Republik Indonesia Nomor 31 Tahun 1999 Jo. Undang-Undang Republik Indonesia Nomor 20 tahun 2001, namun di persempit dengan spesifikasi berupa: yang nyata dan pasti jumlahnya akibat perbuatan melawan hukum baik sengaja maupun lalai ${ }^{1}$.

Kerugian keuangan negara harus nyata dan pasti jumlahnya sebanding dengan pengertian keuangan negara itu sendiri, menurut M. Yusuf Jhon² termasuk merupakan kerugian keuangan negara adalah pemborosan yang berbentuk:

1. Perbuatan Melawan Hukum (PMH) mengeluarkan uang untuk sesuatu yang tidak direncanakan oleh Negara/daerah, tidak didasarkan pada analisis kebutuhan, serta tidak di anggarkan.

2. Berkurangnya hak daerah, karena hilangnya pendapatan (yang sudah masuk sebagai pendapatan maupun yang sifatnya potensi pendapatan).

3. Bertambahnya kewajiban (kriteria untuk menentukan bertambahnya kewajiban ini adalah terdapat PMH atau tidak) yang tidak dianggarkan untuk oknum pejabat, bukan untuk kepentingan negara.

4. Pembayaran lebih atas nilai yang seharusnya di bayar: a. pembayaran atas kegiatan yang volumenya kurang atau tidak sesuai spesifikasi; b. pembayaran atas proyek yang belum selesai; c. pembayaran atas barang/jasa yang melebihi harga pasar;

5. Pembelian dengan nilai yang tinggi dengan harga pasar atau pembandingnya dengan spesifikasi, tempat, dan tahun yang sama, maka selisih harga merupakan kerugian (bukan pemborosan).

Selain hal tersebut di atas, kerugian keuangan negara dalam dimensi hukum administrasi negara juga akan selalu merujuk kepada legalitas, yang mempunyai inti pada wewenang untuk menentukan kerugian keuangan negara sehingga memiliki legitimasi.

Menurut Undang-Undang Republik Indonesia Nomor 15 Tahun 2006 tentang BPK. BPK merupakan satu lembaga negara yang bebas dan mandiri dalam memeriksa pengelolaan dan tanggung jawab negara. BPK berkedudukan di ibukota negara. BPK

\footnotetext{
1 Undang-Undang Republik Indonesia Nomor 15 Tahun 2006 tentang BPK

2 M. Yusuf Jhon dan Dwi Setiawan, Kiat Memahami Pemeriksaan Laporan Keuangan Pemerintah Daerah di Indonesia, Jakarta: Gramedia Pustaka Utama, 2009. hlm, 103-105
} 
memiliki perwakilan di setiap provinsi ${ }^{3}$. Selaku lembaga negara, Badan Pemeriksa Keuangan (BPK) memiliki kedudukan melakukan pemeriksaan pengelolaan dan tanggung jawab keuangan negara sebagai bentuk pelaksanaan kedaulatan rakyat yang sebagaimana diatur pada Pasal 23E,23F,dan 23G Undang-Undang Dasar Negara Republik Indonesia 1945. Pelaksanaan Kedaulatan rakyat dalam wujud pemeriksaan pengelolaan dan tanggung jawab keuangan negara harus di pertanggungjawabkan kepada Dewan Perwakilan Rakyat sebagai Wakil Rakyat.

Dalam teori kelembagaan mengembangkan Teori klasik Trias Politika Montesquieau telah menancapkan Teorisasi fundamental ketatanegaraan dengan mengemukakan organisasi kekuasaan sebuah negara atas kekuasaan legislatif, Eksekutif dan Yudikatif. Kekuasaan Legislatif yang membentuk Peraturan, eksekutif mengeluarkan keputusan dan Putusan sebagai produk Yudikatif. Montesquieau memahamkan bahwa Hubungan ketiga kekuasaan itu diletakkan terpisah, yang kemudian dikenal dalam konsepsi Pemisahan Kekuasaan ${ }^{4}$. Sehingga BPK memiliki kekuasaan atas pengelolaan dan tanggung jawab keuangan negara dalam Hukum Keuangan Negara.

Dengan demikian BPK memiliki kewenangan penuh atas pemeriksaan kerugian keuangan negara dan menetapkannya karena anggaran belanja APBN/D adalah sumber dari segala penyelenggaraan negara. Seharusnya penyelenggaraan negara dengan adanya anggaran APBN/D merupakan tolak ukur bahwa pemerintah harus transparan dan akuntabel dalam setiap kegiatan pemerintah yang seharusnya di laksanakan bukan yang tidak ada dalam agenda tahunan menjadi pengelolaan keuangan di luar dugaan. Sehingga disisi inilah BPK memiliki peranan untuk menindaklanjuti atas kewenangan jabatan pemerintah dalam pengelolaan keuangan, dan kewenangan lembaga BPK atau BPKP dalam menetapkan kerugian keuangan negara.

\section{METODE PENELITIAN}

Berdasarkan Penelitian yang di lakukan oleh peneliti, menggunakan konsep penelitian/tipe penelitian normatif yang mana penelitian ini menggunakan literatur berdasarkan perundang-undangan dan kepustakaan serta jurnal-jurnal hukum yang memiliki subjek Hukum Keuangan Negara.

3 Pasal 2 dan Pasal 3 ayat 1 dan 2, Undang-Undang Republik Indonesia Nomor 15 Tahun 2006 tentang BPK

4 Kamaruddin Jafar, Menguji 'Positive Legislature' sebagai Kewenangan Mahkamah Konstitusi, Halu Oleo Law Review, Volume 1 Issue 2, September 2017 http://ojs.uho.ac.id/index.php/holrev/h.247, diaskes pada tanggal 31 Maret 2019, hlm. 246-251. 


\section{ANALISIS DAN PEMBAHASAN}

\section{Timbulnya Kerugian Keuangan Negara}

Keuangan negara merupakan jantung dari kehidupan negara. pemerintah tidak akan efektif jika keuangan negara mengalami gangguan secara fisik, karena semua aktivitas pemerintahan dan pembangunan dibiayai dengan tersedianya keuangan negara yang cukup dan memadai. Sumber keuangan negara dikelola antara lain dari eksploitasi sumber daya alam (pertambangan, kehutanan, kelautan, perikanan, pertanian dan perkebunan), pembayaran pajak oleh masyarakat, pengelolaan BUMN/BUMD penerimaan hibah, pinjaman luar negeri dan lain-lain penerimaan negara yang sah menurut undang-undang.

Pengelolaan keuangan negara dilakukan oleh presiden sebagai kepala pemerintahan negara karena merupakan bagian yang tak terpisahkan dari pemerintahan negara. Dalam melakukan pengelolaan keuangan negara, presiden di bantu oleh beberapa pihak yang dianggap mampu dan cakap di bidang keuangan negara sebagaimana telah dibahas sebelumnya.

Sebagai dasar untuk mengkaji substansi timbulnya kerugian keuangan negara, yakni kaidah hukum keuangan negara. Adapun kaidah hukum keuangan negara yang dijadikan dasar terdapat pada Pasal 35 ayat (1) Undang-Undang Keuangan Negara Jo. Pasal 59 ayat (2) Undang-Undang Pemeriksaan Pengelolaan dan Tanggung Jawab Keuangan Negara. Sehingga kaidah hukum di atas sangat Representatif dijadikan landasan untuk mengkaji timbulnya kerugian keuangan negara.

Pasal 35 ayat (1) Undang-Undang Keuangan Negara, ditegaskan bahwa setiap pejabat negara dan pegawai negeri bukan bendahara yang melanggar hukum atau melalaikan kewajibannya baik langsung dan tidak langsung yang merugikan keuangan negara diwajibkan mengganti kerugian yang di maksud. Kemudian, Pasal 59 (2) UndangUndang Pemeriksaan Pengelolaan dan Tanggung Jawab Keuangan Negara, Menegaskan bahwa bendahara, Pegawai Negeri bukan bendahara atau pejabat lain yang karena perbuatannya melanggar hukum atau melalaikan kewajiban yang dibebankan kepadanya secara langsung merugikan keuangan negara, wajib mengganti kerugian tersebut.

Berpijak kepada kedua kaidah hukum keuangan negara tersebut, maka timbulnya kerugian keuangan negara, disebabkan oleh:

a) Pejabat Negara, Bendahara, pegawai negeri bukan bendahara, atau pejabat lain;

b) Perbuatan yang ketidaksesuaian dengan hukum; atau 
c) Perbuatan melalaikan kewajiban hukum dibebankan.

Melalaikan kewajiban hukum yang menimbulkan kerugian keuangan negara, pada hakikatnya terjadi pada saat tidak memenuhi kewajiban yang diwajibkan oleh hukum keuangan negara. Tidak memenuhi kewajiban hukum misalnya pengelola keuangan negara berhak melakukan penagihan tetapi tidak dilakukan sehingga menimbulkan kerugian keuangan negara. Hal inilah yang tanpa disadari oleh pengelola keuangan negara dalam rangka mengelola keuangan negara sehingga hak menagih dari negara dinyatakan kadaluwarsa. Hukum keuangan negara meletakkan hak bagi negara untuk melakukan penagihan tetapi hak itu dilakukan sehingga negara mengalami kerugian keuangan negara.

Timbulnya kerugian keuangan negara menurut Yunus Husein ${ }^{5}$ sangat terkait dengan berbagai transaksi, seperti transaksi barang dan jasa, transaksi yang terkait dengan utang piutang, dan transaksi yang terkait dengan biaya dan pendapatan. Dalam kaitan ini, Djoko Sumaryanto $(2009 ; 40)^{6}$ mengemukakan beberapa kemungkinan terjadi kerugian keuangan negara sebagai berikut:

a) Terdapat pengadaan barang-barang dengan harga yang tidak wajar karena jauh di atas harga pasar, sehingga merugikan keuangan negara sebesar selisih harga pembelian dengan harga pasar atau harga yang sewajarnya.

b) Harga pengadaan barang dan jasa wajar. Wajar tetapi tidak sesuai dengan spesifikasi barang dan jasa yang dipersyaratkan. Kalau harga barang dan jasa murah, tetapi kualitas barang dan jasa kurang baik, maka dapat di katakana juga merugikan keuangan negara.

c) Terdapat transaksi yang memperbesar utang negara secara tidak wajar, sehingga dapat dikatakan merugikan keuangan negara karena kewajiban negara untuk membayar utang semakin besar.

d) Piutang negara berkurang secara tidak wajar dapat juga dikatakan merugikan keuangan negara.

e) Kerugian negara dapat terjadi kalau aset negara berkurang karena dijual dengan harga yang murah atau dihibahkan kepada pihak lain atau ditukar dengan pihak swasta atau perorangan (ruislag).

5 Yunus Husein. Kerugian Negara Dalam Tipikor, Jakarta: Koran Seputar Indonesia, 2008. hlm, 7.

6 Djoko Sumaryanto, Pembalikan Beban Pembuktian Tindak Pidana Korupsi dalam Rangka Pengembalian Kerugian Keuangan Negara, Jakarta: Prestasi Pustaka, 2009. hlm. 40. 
f) Untuk merugikan negara adalah dengan memperbesar biaya instansi atau perusahaan. Hal ini dapat terjadi baik karena pemborosan maupun dengan cara lain, seperti membuat biaya fiktif. Dengan biaya yang diperbesar, keuntungan perusahaan yang menjadi objek pajak semakin kecil.

g) Hasil penjualan suatu perusahaan dilaporkan lebih kecil dari penjualan sebenarnya, sehingga mengurangi penerimaan resmi perusahaan tersebut.

Good financial governance (GFG) mengadopsi prinsip tata kelola pemerintahan yang baik (Good Governance) dengan mengedepankan empat aspek penting7:

a. Transparansi dalam pengelolaan keuangan negara;

b. Akuntabilitas dalam pengelolaan keuangan negara;

c. Keadilan dalam pengelolaan keuangan negara, dan;

d. Partisipasi masyarakat dalam pengelolaan keuangan negara.

\section{Pemeriksaan Pengelolaan Keuangan Negara merupakan Kewenangan BPK atau BPKP}

Pengelolaan keuangan negara merupakan bagian dari pelaksanaan pemerintahan negara. Pengelolaan keuangan negara adalah keseluruhan kegiatan pejabat pengelola keuangan negara sesuai dengan kedudukan dan kewenangannya, yang meliputi perencanaan, pelaksanaan, pengawasan, pertanggungjawaban, dan pemeriksaan keuangan negara.

Penegakkan hukum dalam pemberantasan perampokan keuangan negara harus dilakukan dengan tegas mulai dari pejabat penangung jawab pengelolaan keuangan, pejabat yang memberikan perintah, pejabat pengguna anggaran, pejabat pengelola keuangan dan administrasi sampai pihak ketiga yang menerima. Keluarnya uang dari kas negara/daerah harus ada keterlibatan seluruh pejabat pengelolaan keuangan negara/daerah baik sebagai penanggung jawab, sebagai pejabat pengguna anggaran, sebagai pejabat yang memimpin unit kerja, sebagai pejabat yang mengelola administrasi, sebagai pejabat yang menyimpan uang di kas negara/daerah, sebagai pejabat yang melakukan pembayaran yang di berikan hak dan kewenangan sesuai ketentuan perundang-undangan.

Pemeriksaan terhadap pengelolaan dan tanggung jawab keuangan negara ini bertujuan untuk penegakan hukum atas penyimpangan terhadap keuangan negara.

\footnotetext{
7 Hendra Karianga, Partisipasi Masyarakat dalam Pengelolaan Keuangan Daerah, Perspektif Hukum dan Demokrasi, Bandung: Alumni. 2011. hlm, 23.
} 
Walaupun kenyataannya banyak penyimpangan terhadap keuangan negara yang mengakibatkan kerugian negara. Faktor penyebabnya disebabkan karena penyalahgunaan keuangan negara baik oleh pemerintah pusat maupun pemerintah daerah. Keadaan ini tidak terlepas dari dampak adanya nepotisme dalam penyelenggaraan pemerintahan di Indonesia. Kurangnya keterbukaan baik dari pejabat pengelolaan keuangan negara, maupun keterbukaan dalam penggunaan keuangan negara. Untuk memberantas KKN, selayaknya pemerintah menindaklanjuti temuan-temuan hasil pemeriksaannya BPK. BPK yang merupakan satu-satunya lembaga yang bertugas memeriksa keuangan negara, terus mengupayakan kinerja yang optimal secara sistematis untuk mempercepat pemberantasan korupsi. Peran strategis BPK sebagai lembaga yang berfungsi melindungi keuangan negara.

Pemeriksaan pengelolaan dan tanggung jawab keuangan negara yang dilakukan oleh Badan Pemeriksa Keuangan wajib berpedoman pada ketentuan yang tercakup dalam hukum keuangan negara. Hal ini bertujuan agar menghasilkan pemeriksaan Badan Pemeriksa Keuangan mencerminkan rasa keadilan, kemanfaatan, dan kepastian hukum sehingga di terima oleh pengelola keuangan sebagai pihak yang terperiksa.

Pemeriksaan pengelolaan dan tanggung jawab keuangan negara pada hakikatnya meliputi pemeriksaan atas pengelolaan keuangan negara dan pemeriksaan atas tanggung jawab keuangan negara. Pemeriksaan itu meliputi seluruh unsur keuangan negara sebagaimana diatur dalam Pasal 2 Undang-Undang Keuangan Negara. ketika terjadi pemeriksaan pengelolaan dan tanggung jawab keuangan negara dilakukan oleh akuntan publik, maka hasil pemeriksaannya wajib di sampaikan kepada Badan Pemeriksa Keuangan dan di publikasikan.

Pengamanan Keuangan Negara tertuju pada terjadinya kerugian keuangan negara yang dialami oleh negara dalam rangka pemenuhan tugas-tugasnya. Harus disadari bahwa pengelolaan dan tanggung jawab keuangan negara kadang kala selalu diikuti dengan kerugian keuangan negara karena rendah atau kurangnya kesadaran hukum pengelola keuangan negara.

Selaku lembaga negara, Badan Pemeriksa Keuangan memiliki kedudukan melakukan pemeriksaan pengelolaan dan tanggung jawab keuangan negara sebagai bentuk pelaksanaan kedaulatan rakyat sebagaimana tersirat dalam Pasal 1 ayat (2) Undang-Undang Dasar Negara Republik Indonesia tahun 1945. Pelaksanaan kedaulatan 
rakyat dalam wujud pemeriksaan pengelolaan dan tanggung jawab keuangan negara harus di pertanggungjawabkan kepada Dewan Perwakilan Rakyat sebagai Wakil rakyat.

Karena kerugian keuangan negara menjadi salah satu pokok atau unsur yang mengikat baik secara personal maupun korporasi, dalam kerugian tidak lepas pula pola pengelolaan keuangan itu sendiri, secara garis besarnya pengelolaan keuangan negara dalam perspektif negara hukum sosial atau sering di sebut Welfare State atau Verzorgingsstaat merupakan amanah dari Pasal 23, Pasal 23A-G dan Pasal 33 UndangUndang Dasar Negara Republik Indonesia Tahun 1945. Keuangan negara dalam perspektif konstitusi harus mencerminkan prinsip-prinsip:

a) Keterbukaan (openness) dan pertanggungjawaban (accountability) untuk sebesar-besarnya kemakmuran rakyat.

b) Demokrasi dalam prosedur (persetujuan parlemen) dan demokrasi dalam substansi (setiap mata anggaran mencerminkan kehendak rakyat).

c) Pengawasan secara auditif (oleh BPK) dan pengawasan secara politik (oleh DPR).

d) Prinsip efisiensi berkeadilan.

e) Keseimbangan dalam kesatuan ekonomi nasional.

f) Kesinambungan (sustainability).

Selain hal tersebut, Kerugian keuangan negara dalam dimensi Hukum Administrasi Negara juga akan selalu merujuk kepada legalitas, yang berintikan pada wewenang untuk menentukan kerugian keuangan negara sehingga memiliki legitimasi.

Sehingga dalam hal ini, peranan dalam Pemeriksaan Keuangan negara yakni BPK yang mana kita ketahui bersama secara konstitusi diatur pada Undang-Undang Dasar Negara Republik Indonesia 1945, dengan amanat pada alinea ke IV maka segala sesuatu tentang kesejahteraan rakyat haruslah sesuai dengan prinsip kepastian hukum, kemanfaatan, keadilan, transparansi dan akuntabel. Demikian pula pemeriksa bertanggungjawab untuk membantu manajemen dan para pengguna laporan hasil pemeriksaan lainnya untuk memahami tanggung jawab pemeriksa berdasarkan standar pemeriksaan dan cakupan pemeriksaan yang di tentukan berdasarkan ketentuan peraturan perundang-undangan yang berlaku.

Dalam rangka membantu pihak manajemen dan para pengguna laporan hasil pemeriksaan lainnya memahami tujuan, jangka waktu, dan data yang diperlukan dalam pemeriksaan. Pemeriksa harus mengomunikasikan informasi yang berkaitan dengan 
perencanaan, pelaksanaan, dan pelaporan pemeriksaan kepada pihak-pihak yang terkait selama tahap perencanaan pemeriksaan.

\section{Bagaimana Mekanisme Penetapan Kerugian Keuangan Negara}

Salah satu dalam pencapaian akuntabilitas adalah pengawasan. Pemahaman tentang pengawasan dikenal dan dikembangkan dalam ilmu manajemen. Pengawasan merupakan salah satu unsur dalam kegiatan pengelolaan. Ilmu manajemen maupun ilmu hukum administrasi pengawasan diartikan sebagai kegiatan mengawasi dalam arti melihat sesuatu dengan seksama, sehingga tidak ada kegiatan lain di luar itu. Melalui mekanisme pengawasan, berbagai aktivitas yang telah digariskan dalam peraturan perundangundangan maka dapat dilaksanakan secara baik dalam arti sesuai dengan apa yang maksud.

Secara garis besar pengaturan tentang pelaksanaan anggaran meliputi: pelaksanaan anggaran pendapatan yaitu: setiap kementerian negara/lembaga/satuan kerja perangkat daerah yang mempunyai sumber pendapatan wajib mengintensifkan perolehan pendapatan yang menjadi wewenang dan tanggung jawabnya. Penerimaan harus disetor ke kas negara/daerah pada waktunya yang selanjutnya diatur dalam peraturan pemerintah.

Pelaksanaan anggaran belanja: pengguna anggaran/kuasa pengguna anggaran melaksanakan kegiatan sebagaimana tersebut dalam dokumen pelaksanaan anggaran yang telah disahkan. Untuk keperluan pelaksanaan anggaran, pengguna anggaran/kuasa pengguna anggaran berwenang mengadakan ikatan/perjanjian dengan pihak lain dalam batas anggaran yang telah di tetapkan.

Pertanggungjawaban pelaksanaan APBN dan APBD, diatur dalam Pasal 30,31, dan 32 Undang-Undang Republik Indonesia Nomor 17 tahun 2003 yaitu sebagai berikut: Presiden menyampaikan rancangan Undang-Undang tentang pertanggungjawaban pelaksanaan APBN kepada DPR berupa laporan keuangan yang telah di periksa oleh Badan Pemeriksa Keuangan selambat-lambatnya 6 (enam) bulan setelah tahun anggaran berakhir. Laporan keuangan dimaksud setidak-tidaknya meliputi Laporan Realisasi APBN, Neraca, Laporan Arus Kas, dan Catatan atas Laporan Keuangan, yang dilampiri, dengan laporan keuangan perusahaan negara dan badan lainnya.

Laporan Keuangan Badan Pemeriksa Keuangan menentukan titik hasil dari hasil pemeriksaan yang di lakukan maka dapat di katakana bahwa pengeluaran arus kas 
Negara/Daerah tidak luput dari pemegang kuasa anggaran yang memiliki kemampuan dan wewenang dalam penggunaannya, dalam perspektif hukum administrasi negara, jabatan merupakan persoalan mendasar berkaitan dengan fungsi negara. negara bersisi berbagai jabatan atau lingkungan kerja tetap dengan berbagai fungsi untuk mencapai tujuan negara ${ }^{8}$. Oleh karenanya, agar jabatan dan fungsi-fungsi tersebut berjalan sebagaimana mestinya untuk mencapai sasaran dan tujuan maka Pejabat adalah orang perorangan yang duduk dan didudukkan dalam suatu jabatan dengan tugas dan wewenang tertentu untuk merealisasikan berbagai fungsi jabatan tertentu ${ }^{9}$.

Dari uraian di atas mekanisme penetapan Kerugian Keuangan negara dilihat dari Siapa yang menggunakan anggaran, adanya laporan keuangan yang di buat untuk pertanggungjawaban di akhir tahun anggaran, dan adanya catatan tentang penggunaan anggaran. Secara spesifik dapat di gambarkan proses dan risiko pelanggaran sehingga menimbulkan kerugian keuangan negara yaitu:

1. Perencanaan anggaran di pemerintah;

2. Penetapan anggaran di legislatif;

3. Pelaksanaan anggaran di pemerintah;

4. Pertanggungjawaban anggaran di pemerintah;

5. Kontrol eksternal (termasuk pemeriksaan BPK).

Sehingga secara substansi dalam melaksanakan pemeriksaan atas laporan keuangan, maka kriteria yang di pakai adalah prinsip akuntansi keuangan yang berlaku. Untuk pemeriksaan kinerja, kriteria yang dipakai adalah efisiensi, efektivitas dan ekonomis. Sedangkan dalam pemeriksaan investigasi, kriteria yang di pakai adalah kerugian keuangan negara dan unsur tindak pidana korupsi. Bentuk temuan atas pemeriksaan di atas antara lain:

a. Penyimpangan yang mengganggu kewajaran penyajian laporan keuangan;

b. Penyimpangan terhadap kriteria/peraturan yang telah ditetapkan;

c. Penyimpangan yang mengganggu asas efisiensi; dan

d. Penyimpangan yang dapat mengakibatkan tidak tercapainya program yang direncanakan.

\footnotetext{
8 Ridwan HR., Hukum Administrasi Negara, Jakarta: Rajawali Press, 2013. hlm, 71-77

9 Yopie Morya Immanuel Patiro, Diskresi Pejabat Publik dan Tindak Pidana Korupsi; Bandung: CV. Keni Media, 2012 hlm, 96.
} 
Secara umum, pemeriksaan BPK dapat menemukan pelanggaran yang bersifat administratif (mal administrasi), yaitu bila tidak ditemukan unsur kerugian keuangan negara baik secara potensial maupun secara nyata, namun hanya terjadi kesalahan dalam pengelolaannya, maka BPK akan memberikan rekomendasi untuk perbaikan serta memantau tindak lanjut atas pelaksanaan dari rekomendasi tersebut. Sifat pelanggaran lainnya adalah tindak pidana, yaitu bila terdapat kerugian negara akibat terjadinya perbuatan melawan hukum dan/atau penyalahgunaan kekuasaan. ${ }^{10}$

\section{KESIMPULAN}

Dari uraian di atas, maka peneliti menyimpulkan:

1. Timbulnya kerugian keuangan negara, yakni kaidah hukum keuangan negara. Adapun kaidah hukum keuangan negara yang dijadikan dasar terdapat pada Pasal 35 ayat (1) Undang-Undang Keuangan Negara Jo. Pasal 59 ayat (2) Undang-Undang Pemeriksaan Pengelolaan dan Tanggung Jawab Keuangan Negara. Sehingga kaidah hukum di atas sangat Representatif dijadikan landasan untuk mengkaji timbulnya kerugian keuangan negara.

2. Berdasarkan kewenangannya dalam penetapan Kerugian Keuangan Negara ialah Pemeriksaan Keuangan negara yakni BPK yang mana kita ketahui bersama secara konstitusi diatur pada Undang-Undang Dasar Negara Republik Indonesia 1945, dengan amanat pada alinea ke IV maka segala sesuatu tentang kesejahteraan rakyat haruslah sesuai dengan prinsip kepastian hukum, kemanfaatan, keadilan, transparansi dan akuntabel.

3. Adanya tindaklanjut hasil laporan Inspektorat Daerah Kabupaten/kota yang mana sebagai lembaga pengawas tingkat kabupaten dan BPKP yang sebagai pengawas wilayah tingkat provinsi, bahwa pelaporan yang diadakan berdasarkan hasil audit yang seksama dan telah di berikan sebelumnya Kepada DPR/DPRD untuk selanjutnya diadakan penetapan kerugian Negara berdasarkan Lembaga Yudisial Sesuai Ketentuan Undang-Undang.

${ }^{10}$ Dikutip dalam karangan Ikhwan Fahrojih, Pengawasan Keuangan Negara "Pemeriksaan Keuangan Negara Melalui Auditor Internal Dan Eksternal Serta DPR, Malang: Intrans Publishing, 2016, hlm. 33. 


\section{Daftar Pustaka}

\section{Buku}

Fahrojih, Ikhwan, Pengawasan Keuangan Negara "Pemeriksaan Keuangan Negara Melalui Auditor Internal Dan Eksternal Serta DPR, Malang: Intrans Publishing, 2016.

HR, Ridwan, Hukum Administrasi Negara, Jakarta: Rajawali Press, 2013

Husein, Yunus. Kerugian Negara Dalam Tipikor, Jakarta: Koran Seputar Indonesia, 2008.

Jhon, M. Yusuf dan Dwi Setiawan, Kiat Memahami Pemeriksaan Laporan Keuangan Pemerintah Daerah di Indonesia, Jakarta: Gramedia Pustaka Utama. 2009.

Karianga, Hendra, Partisipasi Masyarakat dalam Pengelolaan Keuangan Daerah, Perspektif Hukum dan Demokrasi, Bandung: Alumni. 2011

Patiro, Yopie Morya Immanuel, Diskresi Pejabat Publik dan Tindak Pidana Korupsi, Bandung: CV. Keni Media.. 2012

Sumaryanto, Djoko, Pembalikan Beban Pembuktian Tindak Pidana Korupsi dalam Rangka Pengembalian Kerugian Keuangan Negara, Prestasi Pustaka, Jakarta, 2009.

\section{Perundang-Undangan}

Undang-Undang Republik Indonesia Nomor 15 Tahun 2006 tentang BPK

Undang-Undang Republik Indonesia Nomor 17 Tahun 2003 tentang Keuangan Negara

\section{e- Journal}

Jafar, Kamaruddin, Menguji 'Positive Legislature' sebagai Kewenangan Mahkamah Konstitusi, Halu Oleo Law Review, Volume 1 Issue 2, September 2017 http://ojs.uho.ac.id/index.php/holrev/h.247, diaskes pada tanggal 31 Maret 2019. 